\title{
Integrated Processing of Secondary Raw Materials as the Main Direction of Ecologization of Beet Sugar Production In The Republic of Kazakhstan
}

\author{
Gulzira Zhaxygulova ${ }^{1, *}$ Maiya Myrzabekova² ${ }^{2}$, and Guzel Sadykova ${ }^{3}$ \\ ${ }^{1}$ Bolu Abant İzzet Baysal University, Faculty of Economics and Administrative Sciences, 14030 \\ Bolu, Turkey \\ ${ }^{2}$ Ankara Haci Bayram Veli University, Academy of Foreign Languages, 06570 Ankara, Turkey \\ ${ }^{3}$ Kastamonu University, Faculty of Economics and Administrative Sciences, 37200 Kastamonu, \\ Turkey
}

\begin{abstract}
Beet sugar production is one of the material-intensive industries, where the volume of raw and auxiliary materials used in production is several times higher than the output of finished products. It is also a source of multi-tonnage secondary resources, i.e. by-products and production waste, the main ones beingAbeet pulp, molasses and filtration sludge. Against the background of the implementation of the Sectoral Program of Beet Sugar Production Development in the Republic of Kazakhstan for 2018-2027, there is a need to create a concept of ecologization of production, which will provide for the development of fundamentally new technologies to ensure minimum waste, combining environmentally friendly methods with cost-effective production of sugar beet and by-products. The bet should be made on low-cost technologies that will minimize production costs and environmental impact. In this article possible variants of sugar beet processing technologies with complex deep processing of waste are offered. The comparison of traditional technology and various variants of progressive technologies of sugar beet processing and production of new products from secondary resources was carried out, which allowed to determine revenue from complex processing of 1 ton of sugar beet.
\end{abstract}

\section{Introduction}

Positive dynamics of sugar production from sugar beet in the Republic of Kazakhstan is due to the development and implementation of the Sectoral Program of beet sugar production development for 2018-2027. Target indicators of the program are the increase in the share of sugar production from domestic raw materials from 12\% (59 thousand tons) in 2018 to $77 \%$ (400 thousand tons) in 2027, sugar beet sown areas from 19.6 thousand hectares to 78 thousand hectares, the increase in beet sugar production from 627 thousand tons to 3330

\footnotetext{
*Corresponding author: gulzirazhaxy@gmail.com
} 
thousand tons (by 5.3 times) [1]. Within the limits of the given program it is started construction of sugar factories in Shu district of Zhambyl region (capacity 116 thousand tons of sugar per year), and also in Bulaevo city of the North-Kazakhstan region (capacity of sugar production of 100 thousand tons per year). In 2021 with the participation of Turkish company "Kayseri Seker Fabrikasi" it is planned to start construction of sugar plant in Pavlodar region. In order to provide raw materials for the future plant in 2019 in the region has already conducted an experimental sowing of sugar beet seeds. As a result of the experiment, a quality crop has been obtained that meets the standards of sugar production [2].

The Sectoral Program for modernization of the existing sugar factories provides for 1,500 million tons of investments and subsidies, expansion of the line for production of dry cake, deep processing products of sugar beet. Thus, the main goal of the state support for Kazakhstan's beet sugar production is to ensure food security in terms of sugar, the main conditions of which are self-sufficiency in food, food and raw material independence, sustainability of the domestic food market, etc. In this regard, research on improving the efficiency of beet raw material processing, based on waste-free production and ecologization, has become particularly relevant. The basis of non-waste production is complex processing of raw materials using all its components. Rational use of resources in sugar beet processing is to get the maximum yield of various finished products with minimum consumption of material, labor, fuel and energy resources.

At the same time, it should be noted that for a long time there was a paradoxical situation in the industry; in fact, the sugar beet processing enterprises in order to increase the economic efficiency of production were aimed at mastering the production of new types of products from the secondary resources of beet sugar production; however, the lack of funds for the renewal of worn-out equipment for the processing of secondary products forced to bear the costs of waste disposal and payment of fines for environmental pollution.

At this stage, diversification of production in Kazakhstan's sugar beet sub-complex should help to improve production efficiency. It should be aimed primarily at mastering production of new types of products from sugar beet waste, i.e. it is necessary to improve and master new production technologies or introduce technological innovations. Among technological innovations, product innovations play a special role. The priority in the development of the sugar beet subcomplex should be the creation of new types of sugar products, including medicinal and preventive purposes, in accordance with the requirements of the state policy in the field of healthy nutrition of the country's population, as well as a range of products with increased food and biological value based on by-products of sugar beet processing.

One of the weak points of Kazakhstan's sugar factories in the functional competition is insignificant production of products of industries technically and technologically connected with the sugar industry. The country's sugar industry is characterized by a low degree of processing of waste and by-products, which contain valuable nutrients and serve as raw material for a number of food industries. Sugar industry in Western Europe, the USA and Turkey offers more than 150 different products of processing of sugar-containing raw materials. In addition, foreign competitors produce more than 30 varieties of marketable sugar, which differ from each other by different content of poly and monosaccharides, presence of vitaminizing and colouring additives. Thus, the external market for sugar products is initially more attractive to consumers.

There is a rather close causal link between pricing policy and diversification of production. The combination of the highly competitive sugar market with the monopolistic markets of citric acid, pectin and other products of sugar-containing raw materials processing will raise the level of competitiveness of the industry. This is achieved due to a more guaranteed profit from production, as the inability to influence the level of the established market price for sugar (hence, the level of profit) in case of their reduction will be 
compensated by a stable inflow of profit from the markets of monopolistic competition or markets with high market conditions.

\section{Methodology}

The secondary resources of beet sugar production include production wastes (filtration sludge, beet tails, "fight" of sugar beet) and by-products, which include cake and molasses. Typically, the by-products are also marketable, have their own price and can be used as finished products without further processing or as raw materials in other industries, i.e. in some cases be secondary raw materials [3]. Sugar industry in Kazakhstan annually accumulates about 500-600 thousand tons of secondary raw materials - beet pulp, treacle, etc., part of which is used as cattle fodder, and part is recycled. With an average sugar yield of $10-12 \%$ beet sugar production gives to the mass of processed sugar beet $80-83 \%$ raw beet pulp, $5-5.5 \%$ molasses, $10-12 \%$ filtration sludge, and in physical terms during the processing of 627 thousand tons of sugar beet in 2019 by our calculations was formed about 510 thousand tons of beet pulp, 32.6 thousand tons of molasses, up to 75 thousand tons of filtration sludge $[4,5]$. Secondary raw material resources will increase in direct proportion to the growth of sugar beet processing volumes and according to the forecasts of the Sectoral Program of beet sugar production development by 2027 will amount to about 2300-2600 thousand tons.

The use of secondary resources of beet sugar production is carried out in three directions: in food industry - for the production of additional products or as components; in agriculture - as fodder varieties and fertilizers; in other branches of national economy (chemical, paint and varnish, mixed fodder, etc.).

Let's consider the main by-products and waste of beet sugar production. One of the main multi-tonnage by-products in beet sugar production is press. It represents the leached chips of a root crop from which sugar has been extracted. The amount of fresh cuttings (yield) can be $65-90 \%$ to the weight of the beet at a dry matter content of $8.3-6.5 \%$. In the dry matter of press includes primarily pectin, fiber, a small amount of protein, sugar, mineral and other substances. In a ton of raw pulp contains up to 80 fodder units, in dry - up to 850 fodder units, i.e. it is almost equal to concentrated feed [6].

Cuttings are traditionally used for raw and dried animal feed, although there are opportunities to produce other products from it, such as pectin, which is used in confectionery and pharmaceutical industries. Pectin is purchased abroad, and the volume of pectin imports is steadily increasing. In this regard, the relevance of creating an efficient, cost-effective pectin production technology is evident.

In fact, of the total amount of pectin produced in the sugar factories of the republic, $5 \%$ of pectin is dried, $35-43 \%$ is fed to livestock in a fresh form, and the rest is used in sour form, while up to $50 \%$ of its nutrients are lost and the quality of pectin is significantly impaired. Sugar oilcake is stored in special storages - pits, but when stored it quickly sour, fermented, forming aggressive sour rind water. Livestock farms, not having sufficient funds, do not always have the opportunity to buy and take out the cuttings by their own forces. This leads to overfilling of cattle storages, decrease in productivity of sugar factories, disturbance of rhythmic work, increase in costs of sugar production, creation of threat of pollution of surface reservoirs with cattle-sour waters.

The main disadvantage of fresh oilcake as a fodder is a high concentration of water. Fresh oilcake contains up to $94 \%$ moisture. It is economically unprofitable to dry such cake, so much of the water from the fresh cake is removed by means of presses. Fresh presses are environmentally friendly. However, when stored in natural conditions for more than three days, it is sour. The method of storage used in the sugar factories of Kazakhstan, absolutely does not meet modern requirements. 
Chemical composition of dried oilcake is close to that of fresh and is equal in nutritional value to wheat and rye bran. The fodder value of the cuttings can be increased by various additives, while obtaining such types of dried cuttings as melasted, amide, bardiana [7].

Small volume of drying cake is associated with high fuel consumption, as well as physical and moral wear and tear of the equipment of cake drying departments. Growth of expenses for fuel, spare parts and accessories has led to high cost price of its production that causes difficulties in realization of this product. For this reason, the majority of sugar plants in the country have abandoned cake drying and incur additional costs for waste disposal. State investment subsidy and preferential crediting of processing enterprises with fixed assets gives hope for positive dynamics.

In Turkey and a number of EU countries biogas plants are operating on beet pulp, where biogas is obtained from this raw material. It is used in the furnaces of the plant's steam boilers, to produce not only thermal energy of two potentials, but also electricity up to $2 \mathrm{MW}$. It is possible to produce $0,4-0,5 \mathrm{~m} 3$ of biogas from $1 \mathrm{~kg}$ of dry beet pulp. After appropriate cleaning, this gas can be used in public utilities. The thermal potential of biogas without purification is about half of the calorific value of natural gas. LFG contains methane, carbon dioxide and small amounts of impurities. Application of a working biogas plant in a sugar beet plant can meet energy needs of the plant in the off-season and provide additional jobs [8].

Treacle (molasses) - a by-product of sugar production, which is separated by centrifugation of the last product. The amount of dry substances in molasses is $82 \%$, including sucrose $-48.4 \%$ and not sugar $-33.6 \%$. Feed value of molasses reaches 76,8 fodder units [9]. Its yield depends on the chemical composition of beet and, mainly, its sugar content. Treacle as sucrose, contained in a concentrated solution of impurities, is the source of a number of valuable food products. Along with its direct use in cattle fodder, molasses are used to produce citric acid, raw alcohol and baking yeast. For example, Taraz sugar plant gives molasses to local distilleries and Almaty yeast plant. Those, in turn, produce raw alcohol and baking yeast from molasses.

Treacle contains mineral and organic substances, including carbohydrates, amino acids, trace elements and others. By digestion of sucrose through lactic acid bacteria get lactic acid. Lactic acid is very valuable for food industry (confectionery, canning, baking, soft drinks, etc.). It is of great importance in the pharmaceutical industry. Also molasses are used to produce vitamin B12, glutamic acid, sodium glutamate, betaine.

In the beginning of 90 -s the construction of citric acid plant with capacity of 3000 tons per year was started at Koksu sugar plant. However, due to the cessation of financing, the construction was stopped. Meanwhile, the production of food acids makes it possible to smooth out seasonal processing of sugar beet, which is important for improving the efficiency of sugar mills. Along with the above mentioned products, it is possible to additionally produce sugar from molasses, as well as fructose, glucose-fructose syrups. The production of citric acid is associated with the production of waste, in particular gypsum sludge used to produce putty. Also molasses are a source for the production of solvents, varnishes and paints. Thus, molasses are one of the few products with a $100 \%$ level of involvement in the economic turnover [10].

The second after the pulp in terms of volume of formation among secondary raw materials in the sugar industry is filtration sludge, according to expert' estimations the volume of its use is about $5-7 \%$. Defecate (filtration sludge) is formed in the treatment of diffused juice in sugar production. Filtration sludge is removed to filtration fields, occupying large land areas that are excluded from active land use. In addition, part of the sludge is washed away by spring water into rivers and polluted. 
There are sufficient scientific developments on the use of filtration sludge in the sugar industry to reduce limestone consumption by $80 \%$ and to reduce the land area occupied by filtration fields.

The chemical composition of the sludge allows it to be used for neutralising acidic soils, increasing the assimilation of inorganic fertilisers in agriculture, and in other industries as a binding agent in the manufacture of sand-lime bricks, agglomerated crushed stone used as insulation, and as an additive in the manufacture of concrete instead of expanded clay. When treating agricultural land with filtration sludge, the stock of assimilated phosphorus, calcium, potassium and magnesium in the soil increases, and the yield of beet increases.

It is relevant to solve the problems associated with the use of beet tails and beet fighting. Beet fighting and beet tails - waste beet sugar production, formed in the process of loading and unloading and transportation and storage work. On average, sugar in these wastes is 30 $40 \%$ less than in the beet. The increase in sugar production from these types of waste is one of the reserves for improving production efficiency at sugar mills. Sugar mills produce a large number of fights and sugar beet tails every year, which are most often sent for feed to livestock.

As a result of diversification of manufacture sugar factories can introduce non-waste production technologies and master release of new kinds of production. However, the processes of diversification are still rarely used at sugar factories. The introduction of scientific developments has been constrained by the lack of funding. Rational use of byproducts and waste will enable sugar mills to generate additional income and increase their profits. In addition, in addition to government subsidies, sufficient own funds will allow the plants to stimulate sugar beet farming by providing seasonal loans for the purchase of seeds, fuel, fertilizers, pesticides, etc., which will be used for the development of the sugar industry.

It is economically expedient to establish deep processing of press and molasses and choose the most acceptable type of secondary processing. Some plants may specialize in the production of bakery yeast and citric acid by concluding contracts with other related enterprises for the supply of molasses to them; others - for the production of raw alcohol or carbon dioxide; third, next to which there are animal feed farms, may conclude long-term contracts with the latter for the supply of raw squeezed and dried press, etc.

Research institutions have developed options for complex processing of secondary raw materials [11]:

1. variant - granulated sugar; molasses (molasses) for livestock feed; raw squeezed cake;

2. variant - sand sugar; molasses (molasses); raw alcohol; carbon dioxide; fodder yeast; raw squeezed cuttings;

3. variant - sand sugar; molasses (molasses); raw alcohol; carbon dioxide; fodder yeast; dried granulated cuttings;

4. variant - granulated sugar; molasses (molasses); citric acid; gypsum sludge; raw squeezed cuttings.

The research results show that all variants can be realized in practice in the context of full complex processing of beet sugar produced in the region. 


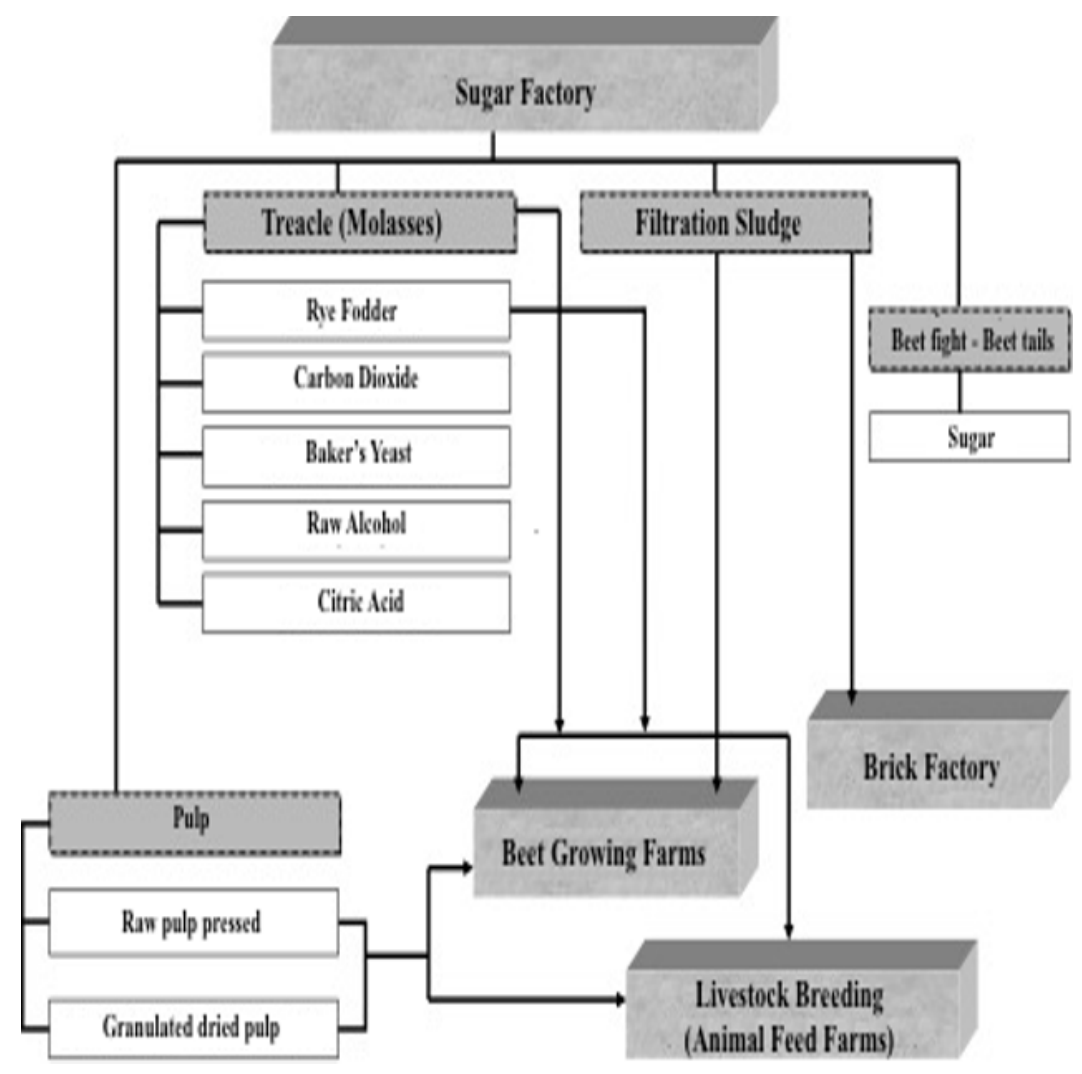

Fig. 1. Recommended recycling structure sugar beet residues

According to the proposed option (Figure 1), part of the press, in raw squeezed form, will be sold to nearby livestock farms. The remaining cake is proposed to be dried and used as cattle fodder. For this purpose, it is proposed to renew the experience of growing and fattening young animals on specialized fattening farms located near sugar mills. At the beginning of fattening the most optimal weight of young growth is considered $280-300 \mathrm{~kg}$, for 120-130 days of fattening the weight reaches $400-500 \mathrm{~kg}$, i.e. net weight - $120-150 \mathrm{~kg}$ per head [12]. Feeding 50 tons of press with the addition of 2.5 tons of straw, about $1 \%$ of concentrated feeds and microdoses (vitamins, minerals, premixes), fattening farms get up to 1 ton of meat, i.e., processing 1 thousand tons of sugar beet, they get 800 tons of press, and when feeding with the above-mentioned additions - 16 tons of beef.

Treacle can be used as valuable fodder in cattle farms in sugar factories. In addition, it is proposed to produce baking yeast, raw alcohol, carbon dioxide and food acids from molasses.

It is recommended to use filtration sludge in agriculture to neutralize acidic soils, increase the digestibility of inorganic fertilizers. For this purpose, part of the sludge should be returned to the beet farm; the rest of this product can be sold to companies producing building materials (silicate bricks, crushed stone, concrete, etc.).

Taking into account the fact that in "combat" and sugar beet tailings sugar is only $1-3 \%$ lower than in whole roots, the creation of appropriate schemes for the processing of sugar beet waste will allow sugar refineries to receive additional 3-4\% of sugar.

We have made a comparison of traditional and sugar beet processing technology with deep processing of waste and production of new products, which allowed us to determine the revenue from complex processing of 1 ton of sugar beet [6] (Table 1). 
Variants of complex processing of sugar beet differ in composition of final products and the value of the revenue.

Table 1. Calculation of revenue from complex processing of $1 \mathrm{t}$ of sugar beet (in 2019 prices), tenge

\begin{tabular}{|c|c|c|c|c|}
\hline \multirow{2}{*}{ Indicators } & \multirow{2}{*}{$\begin{array}{l}\text { Output from } \\
\text { 1t of beets }\end{array}$} & \multirow{2}{*}{$\begin{array}{l}\text { Wholesale } \\
\text { price, } \\
\text { tenge / t }\end{array}$} & \multicolumn{2}{|c|}{ Revenue } \\
\hline & & & tenge & $\%$ \\
\hline \multicolumn{5}{|c|}{ Option 1 (traditional technology) } \\
\hline Sugar sand, $\mathrm{t}$ & 0,1174 & 180000 & 21130 & 88,37 \\
\hline Feed molasses, $\mathrm{t}$ & 0,051 & 20000 & 1020 & 4,26 \\
\hline Raw cuttings, $\mathrm{t}$ & 0,830 & 950 & 1760 & 7,37 \\
\hline Total & - & - & 23910 & 100 \\
\hline \multicolumn{5}{|c|}{ Option 2 (traditional technology) } \\
\hline Sugar sand, $\mathrm{t}$ & 0,1174 & 180000 & 21130 & 76 \\
\hline Raw liquor, $\mathrm{t}$ & 1,632 & 2800 & 4569 & 16,43 \\
\hline Feed yeast, $\mathrm{t}$ & 0,0031 & 110000 & 341 & 1,23 \\
\hline Raw cuttings, $\mathrm{t}$ & 0,830 & 950 & 1760 & 6,34 \\
\hline Total & - & - & 27800 & 100 \\
\hline \multicolumn{5}{|c|}{ Option 3 (deep molasses processing) } \\
\hline Sugar sand, $\mathrm{t}$ & 0,1174 & 180000 & 21130 & 63,6 \\
\hline Raw liquor, $\mathrm{t}$ & 1,632 & 3200 & 5220 & 15,7 \\
\hline Carbon dioxide, $\mathrm{t}$ & 0,17 & 26000 & 4420 & 13,3 \\
\hline Feed yeast, $\mathrm{t}$ & 0,0031 & 110000 & 340 & 1,02 \\
\hline Dried pellet cuttings, $\mathrm{t}$ & 0,057 & 37000 & 2110 & 6,38 \\
\hline Total & - & - & 33220 & 100 \\
\hline \multicolumn{5}{|c|}{ Option 4 (Deep Crimp Processing) } \\
\hline Sugar sand, $\mathrm{t}$ & 0,1174 & 180000 & 21130 & 71,97 \\
\hline Citric acid, $\mathrm{t}$ & 0,012 & 520000 & 6240 & 21,25 \\
\hline Hypsoschlamm, t & 0,024 & 9520 & 228 & 0,78 \\
\hline Raw cuttings, $\mathrm{t}$ & 0,830 & 950 & 1760 & 6,0 \\
\hline Total & - & - & 29358 & 100 \\
\hline
\end{tabular}

The results of calculations show that the options are characterized by different economic effects, but all of them can be implemented in practice. The final decision on structure of manufacture of production from a beet is expedient to make at working out of the optimum plan-forecast of manufacture for branch taking into account satisfaction of requirement of a national economy in all necessary products of processing of beet raw materials.

Introduction of new effective technologies of complex processing of sugar beet will considerably improve the indicators of the branch, will give a big output of the product, will reduce the amount of wastes, will increase ecological stability. Besides, highly profitable technologies will create an opportunity to organize new production and new workplaces [6].

The direct connection of qualitative growth with ecologization of production is manifested not only at the level of direct reduction of material and energy intensity of industrial products, but also when replacing the materials themselves with more environmentally friendly by their chemical nature and production technologies. When increasing the production of sugar from local raw materials, the environmental aspect should be taken into account, as "... population and nature create an integral ecosystem. Domestically produced food products are ecologically compatible with the physiology of end users" 
$[13,14,15]$. Consideration of this aspect may become one of the promising areas of modern research in the field of nutrition ecology.

\section{References}

1. Diversifikaciya oroshaemyh zemel' na 2018-2027 gody [Diversification of irrigated lands for 2018-2027 years], Ministerstvo sel'skogo hozyajstva Respubliki Kazahstan, https://moa.gov.kz/documents/1548057166.pdf (17.02.2020)

2. Saharnyj zavod budet postroen v Pavlodarskoj oblasti [Sugar factory will be built in Pavlodar region], Ministerstvo sel'skogo hozyajstva Respubliki Kazahstan, https://moa.gov.kz/ru/post/581 (17.02.2020) (Russian)

3. M.I. Egorova, M.B. Konovalov, YU.A. Lopateev, Vtorichnye syr'evye resursy i othody: nauchnyj podhod [Secondary raw materials and waste: A scientific approach], Sahar, 3, 44-45 (2002)

4. M.V. Protasova, S.YU. Mironov, O.V. Luk'yanchikova, L.A. Babkina, Perspektivnye napravleniya ispol'zovaniya othodov saharnogo proizvodstva [Promising areas of the use of sugar production wastes], Auditorium. Elektronnyj nauchnyj zhurnal Kurskogo gosudarstvennogo universiteta, 2(10) (2016)

5. I.P. Saltyk, ZH.A. Gorobec, YU.I. Bolohonceva, Vnedrenie resursosberegayushchih, ekologicheski bezopasnyh tekhnologij i organizaciya vtorichnoj pererabotki othodov v sveklosaharnom proizvodstve [Implementation of resource-saving, environmentally friendly technologies and organization of waste recycling in beet sugar production], Regional'naya ekonomika: teoriya i praktika, 31(88), 51-65 (2008)

6. L.A. Sabetova, M.V. Levina, Napravleniya ispol'zovaniya vtorichnyh othodov sveklosaharnogo proizvodstva [Perspective directions of secondary waste utilization beet sugar production], Tekhnologii pishchevoj i pererabatyvayushchej promyshlennosti APK-produkty zdorovogo pitaniya, 5, 132-141 (2017)

7. A.T. Kalinin, A.A. Kalinin, Narodnohozyajstvennoe znachenie saharnoj svekly [The national economic value of sugar beet], Saharnaya svekla, 7, 5-7 (2002)

8. R.Y. Dyganova, Z.R. Zaynasheva, Tekhnologiya pererabotki sveklovichnogo zhoma s ispolzovaniem bioenergeticheskoj ustanovki [Beet pulp processing technology using bioenergetic machinery], Uchenye zapiski Kazanskoj gosudarstvennoj akademii veterinarnoj mediciny im. N.E. Baumana, 1, 64-67 (2015)

9. Y.I. Lebedev, Kompleksnoe ispol'zovanie syr'ya v pishchevoj i pererabatyvayushchej promyshlennosti [Integrated use of raw materials in the food and processing industry] (Moscow, Legkaya i pishchevaya prom-st', 1982)

10. S.K. Neuymin, D.S. Neuymin, Sotsial'no-ekonomicheskiy karkas territorii regiona: raschet $\mathrm{i}$ analiz [Social and economic framework of the territory of the region: calculation and analysis], Biotika, 7(6), 226-231 (2015)

11. I.D. Blazh, V.I. Komarov, I.A. Ladyzhanskij, Ekonomicheskij mekhanizm intensifikacii ispol'zovaniya syr'ya $v$ pishchevoj promyshlennosti [The economic mechanism of intensification of the use of raw materials in the food industry] (Kishinev, Shtiinca, 1990)

12. N.S. Skugorev, Svekla i sahar Kazahstana (vchera, segodnya, zavtra) [Beet and sugar of Kazakhstan: yesterday, today, tomorrow], Saharnaya svekla, 7, 11-16 (2002)

13. Y.Y. Zhogoleva, Metodologiya razrabotki prioritetov agrarnoj politiki Rossii [Methodology for the development of priorities of the agrarian policy of Russia] (Moscow, Informatik, 1996) 
14. Mutanov, G., Ziyadin, S. /E3S Web of Conferences, DOI: 10.1051/e3sconf/201913504056 (2019)

15. Ziyadin, S., Streltsova, E., Borodin, A., Kiseleva, N., Yakovenko, I., \& Baimukhanbetova, E. Sustainability, 11(9), 2544. (2019). DOI: 10.3390/su11092544 